\title{
Preliminary Remarks on the Interdisciplinary Nature of Anthropolinguistics
}

\author{
Jan Franciszek Nosowicz ${ }^{1, *}$, Joanna Szerszunowicz ${ }^{2}$ \\ ${ }^{1}$ Department of History, Institute of Information and Book Studies, The University of Warsaw, Poland \\ ${ }^{2}$ Department of Philology, Institute of Polish Philology, The University of Bialystok, Poland
}

Copyright $(\subset 2015$ by authors, all rights reserved. Authors agree that this article remains permanently open access under the terms of the Creative Commons Attribution License 4.0 International License

\begin{abstract}
Anthropolinguistics is a relatively new branch of science, whose aim is to research the evolution of human intelligence in a given period reflected in the language evolution in a corresponding time framework. Since the specialization is the main tendency in the human mentality development, this process can be observed during the constant emergence and progress of new branches of science. The specialization of knowledge involves the differentiation of vocabulary, so it results in the creation of new lexical items, which takes place in a given ethnic community at a definite time. Therefore, in a contrastive perspective, it can be expected that the development of vocabulary may differ across the communities. The anthropolinguistic research studies tend to comprise multidirectional analyses on a given element of the mentality of man in various periods. Due to linguo-cultural character and complexity of the researched phenomena, anthropolinguistics has to involve an interdisciplinary approach to the analyzed issues, which means that the analysis of a particular phenomenon requires multiaspectual studies, which comprise conducting research on it in more than one field. The aim of the paper is to present the progress and the most important achievements of anthropolinguistics with a focus on its interdisciplinary nature.
\end{abstract}

Keywords Anthropolinguistics, Evolution, Language, Culture, Language Development, Lexis, Terminology

\section{Introduction}

The recent research on the evolution of man as a creature able to think, comprising studies in many various branches of science, shows that the nature of thinking is different during particular stages of the development of human abilities to think. This fact is reflected in the historical development of lexis, mostly in nominations. As a result of synchronic comparison of terminologies, viewed as a way of formalization of the notional systems in various epochs in the history of mankind, it is possible to determine the rate of development of a given fragment of the notional picture of the world, its quantitative and qualitative historical variations, the stages of specialization as well as the creation of branches of particular disciplines. One can treat is as a basis for the research aiming at determining the causes and conditions favoring the development of science. It also enables reconstructing the historical state and development tendencies of a given culture [1]. These issues are analyzed within the field of anthropolinguistics, which will be discussed in the present paper as a branch of science, which involves an interdisciplinary approach to the analyzed phenomena.

\section{Methodology}

The aim of the paper is to discuss the interdisciplinary nature of anthropolinguistics - the branch of science which focuses on the reconstruction of the fragments of the human evolution reflected in the language development in a particular period. In order to present its specifics, features and goals, the findings of anthropological studies are analyzed from a theoretical perspective. The paper contains a review of literature on anthropolinguistics, with a special focus on its interdisciplinary character. On the basis of the analysis of the contents of the papers and books on the research conducted within the framework of anthropolinguistics, the article outlines the development and specifics of this discipline. The paper highlights and exemplifies the most important aspects of the interdisciplinary nature of anthropolinguistics.

\section{Results}

In 2004, in Bialystok, the international conference Język $i$ kultura [Language and Culture] took place. The participants came from the Western Europe (Denmark, Germany and 
Great Britain) as well as from Poland, Russia and Ukraine ${ }^{1}$. The scientists, specializing in lexicology, terminological and cognitive linguistics as well as in contrastive studies, signed Manifest Biatostocki [Białystok Manifesto], in which they proclaimed the emergence of anthropolinguistics. The manifesto is a program, in which the assumptions of the interdisciplinary branch and its basic characteristics are presented. It is assumed that in the research studies on scientific disciplines, it is possible to distinguish three stages of their development:

- pre-scientific stage, prior to the emergence of the modern science, which uses naive images and notions,

- proto-scientific stage (i.e. early, primitive-scientific) which uses specialized notions, whose names are proto-terms,

- $\quad$ scientific stage which uses notions and terms, which are clearly defined for a given branch of science.

Many scientists started to take a keen interest in these issues. As a result of their studies, an anthropolinguistic journal started to be published $[2]^{2}$ and in the next year a course book for students was available [3].

The main assumption of anthropolinguistics consists in the belief that specialization is the main tendency in the development in the human mentality, occurring with the progress and emerging of new branches. The specialization of knowledge involves the differentiation of the lexicon, i.e. differentiating meanings of words by introducing new lexical elements. Generally, the whole civilization progress (i.e. the development of man or the development of knowledge and culture), can be viewed as a continuous process disposing of semantic syncretism of vocabulary, first of all, cognitive syncretism, i.e. perceiving certain objects as a whole, which results from the lack of the ability to analyze and synthetize (occurring e.g. in infants). According to the general theory of evolution, ontogenesis is a repetition of phylogenesis. It regards both the evolution of human thinking and mentality and language. It is mutual: on the basis of phylogenesis, one can predict the development of a child and certain characteristics of the child's development can be projected on the potential characteristics of man at different stages of the evolution. The available results of research on the intellectual development of children, concerning the increase of the amount of lexis, show the similarity of the early stages of the development of the lexical picture of the world in children and man.

The similarity of the psychological development is reflected not only in lexis. Strelau [4] observes that in the Old English the future tense did not exist, which proves the lack of a respective notion, and - according to the data from studies on children's psychology - three-year-olds understand the meaning of words today and yesterday, but they do not know what tomorrow is. The basic characteristics of

1 Manifest Białostocki was signed by: S. Griniew, W. Lejczyk, A. Ławrowa, J. F. Nosowicz, W. Nowodranowa, H. Picht, T. Skopiuk, P. Thomas and many other scholars.

2 In this volume, "Manifest Białostocki" was published in Polish, English and Russian. the initial stage of thinking - naive thinking of early man and children overlap: in both cases the meanings of the words are vague and there are no strict scientific classifications. Only after a given period in the development, the meanings become more precise and regrouped in the process of the acquisition of new lexis.

The oldest, initial kind of thinking (i.e. intellectual effort) - so-called naive - uses colloquial languages and phraseological units. It is based on life wisdom and common sense and language users operate by everyday general expressions. The imagery, as shown by the meanings of the words, had a general character. For example, the word apple comes from the IE one * haébl, haebōl or PIE *abh, meaning 'moist, juicy' (in Sanskrit - jambu, Lithuanian -óbuolys, Prussian - woble, German - Apfel, English apple, Celtic - avhal, abhal, ull etc) [5] $]^{3}$. In the Greek language the apple is called melon ('fruit'), from which the Latin name of the apple was derived - malum, malus, which can be traced in the root of its Portugese equivalent maçã. The Latin word pōmum ("fruit) ${ }^{4}$ is the basis for the French name of the apple-pomme and the Italian name pomo.

In the Renaissance Europe, as a result of the development of trade and intensive migration, other exotic fruit were also called apples. It is worth adding that the word apple initially was used with reference to all kinds of fruit and even vegetables, which can be observed in such words as German Apfelsine ('orange' - literally Cinese apple), French pomme de terre ('potatoes' - lit. ground apple), Italian pomo d'oro, pomodoro ('tomato' - lit. gold apple), Polish pomarańcza (Italian pomo 'apple' + arancia 'orange'; cf. Italian arancione - adjective 'orange'). It can be explained by the fact that the apple was the oldest fruit ,discovered" by man, and, as a consequence, any other kind of fruit or vegetable was called apple. The differentiation of fruit names occurred much later and then the need for new words arose.

Such facts can facilitate the determination of the order, in which given objects and activities were discovered (and named) or acquired by man, while there are no other proofs of it, apart from the linguistic ones. Therefore, it is possible to determine the level of intellectual development of man or the level of his mental maturity (in relation to the present age of becoming mature) in particular historical periods. Then, it allows for more precisely determining the reasons for given activities and behaviors of persons. It also enables determining the real meaning of historical texts and general rules of human thinking.

The aim of anthropology is to do research on societies, whose institutions differ from the peculiarities of the subject of anthropology known to the researcher: researching a given kind of societies, focusing on a subjective aspect in researching the cultural phenomena and a holistic approach to man and culture. The determination of a multistage character of the development of the mentality of man in the course of the creation of the contemporary civilization contributes to general theory of evolution and it makes it

3 The Old English form of the word is ceppel [5].

4 The Latin term for an apple tree is pömus [6]. 
possible to conduct multidirectional in-depth research on the mentality of man in various periods of evolution, which is the domain of anthropolinguistics. It is related to research on verbal behavior (speaking and understanding) and analyses of language and texts because of traces of old and contemporary national culture which they contain [7].

In 2011, a book by Chruszczewski titled Językoznawstwo antropologiczne. Zadania $i$ metody [Anthropological linguistics. Objectives and methods] was published [8]. It discusses the relations of language and culture as well as cross-cultural communication. This synthetic publication of historical-theoretical enables analyzing various approaches, conceptions and theories on many dimensions of research on language in a broad perspective, conditioned by the presence of symbols. Discussing the issues, Chruszczewski states that man is an element of culture and cultural linguistics is based on the analysis of the names reflecting the perception of nations. Anthropology of culture deals with broad subjects regarding various and distant cultures, such as Indian tribes, described by B. Malinowski [9], who researched the tribes inhabiting the islands of Tobriando and presented the results in his book Życie seksualne dzikich [Sexual life of savages]). According to Chruszczewski, anthropology of culture belongs to sciences of culture and society, researching the cultural heritage, contemporary patterns of thinking and acting as well as artefacts (material and symbolic) and structure (ethnic and social) of man.

However, the author also draws attention to the fact that in the contemporary reality the subject of anthropology changes. It is a consequence of the disappearance of primary societies and the onset of acculturation and the new cultural phenomena, such as the ethnic awareness, nationalism and specific elements of culture of western societies. Changes are also observed in the holistic approach to culture and man as well as in the analysis of cultural phenomena related to man perceived as a being who thinks, experiences, feels etc. The so-called "information explosion" - that is the extremely rapid growth in the flow of scientific and technological information - caused a terminological explosion, an enormous growth in the number of new terms [10].

Thus, according to Chruszczewski, anthropological linguistics is an interdisciplinary discipline, which provides means and tools for a multidimensional analysis and description of language defined as a symbolical system based on social and cultural patterns of human behavior. Such patterns are observed in studies on humor, politeness, political discourse or changes of the language itself, which are the result of contacts of communities who participate in the process of communication [11]. The comprehension of the schemata are used by persons from different cultures is important for translators and interpreters. The foundations of anthropolinguistic research are based on three key elements: language, culture and communication. Anthropology and its history comprises sociolinguistics (e.g. studies on social varieties of language); discourse anthropology (religious, political, legal); textology; history of writing development, including runology ${ }^{5}$ ); language philosophy and theory of translation.

\section{Discussion and Conclusion}

By means of anthropological analyses, researchers can investigate the process of special knowledge growth by studying cultural, historical and social factors influencing the development of specialized vocabulary. Therefore, thanks to its interdisciplinary character, one can conduct an in-depth analysis of the specific character of this part of the lexicon of a given language. The advantages of using such methods are manifold: within the framework of anthropolinguistics, it is possible to use many methods, for instance: a historical comparison, a reconstruction of historical stages, the study of general tendencies of language evolution, a semantic field approach, systematic diachronic studies (both terminological and lexical), a cross-linguistic analysis [13]. The research on the terms used in a given language allows for conducting an analysis of the terminology of this language in various periods. Such studies contribute to tracing different notional systems, which can be compared. The results of such analyses of the terminologies of given languages may be compared, so that the differences and similarities can be observed. It is worth adding that dictionaries constitute an important source of information, especially if they provide the chronological information on given lexical items.

Although, as already mentioned, anthropolinguistics is a relatively new branch of sicence, it should be emphasized that the origins of anthropolinguistics can be traced back to earlier epochs. According to Lachur [14], the theory of structuralism, which was a very important stage in the development of the twentieth-century, had a weak point. The researchers treated the language system as a unique, independent object of research and did not take into consideration the fact that a language is a product of culture and a means of social communication, used in given situations by various senders and receivers. In other words, in the structural approach, a language was analyzed without taking into account cultural conditions and mental processes occurring in users. As a result of the limitations of structuralism new disciplines began to emerge - bridging linguistics and other sciences on the society - aiming at conducting a multiaspectual analysis of relations of the language system and the conditions of its realization in given speech acts.

In the years proceeding the Second World War, ethnolinguistics developed - the science on the language and culture relation. It is the oldest of the disciplines situated on the borders of linguistics proper. It stems from the American anthropological language studies ${ }^{6}$, which accounts for the

5 Runes are the oldest North European writing system, found on stones in Great Britain, Island and Scandinavia. A rune is "a character in an ancient script of 24 angular letters, usually cut on wood or carved in stone, and known either as the runic alphabet or Futhark/Futhorc (...)" [12].

6 It was represented by F. Boas, E. Sapir and B. L. Whorf, who were pioneers of the studies and whose works were of great importance for the development of the discipline. 
two other names of the branch: anthropological linguistics and cultural linguistics. These terms refer to the branches of linguistics, whose aim is to analyze the relation between language, culture, man (society) and realty, which actually refer to beliefs expressed at the turn of $18^{\text {th }}$ and $19^{\text {th }}$ centuries, with Wilhelm von Humboldt as one of the most important representatives. Those ideas started to be developed by Franz Boas and his students as well as followers ${ }^{7}$. In the American school, there were the three key elements, which is reflected in the title of Benjamin Whorf's book - Language, Thought and Reality $^{8}$. The co-author of Sapir-Whorf hypothesis ${ }^{9}$ assumes that human thinking is closely related to the structure of language, which man uses for communication. The relation is mutual: a language influences the way of thinking about the reality, and thinking about the reality influences the language, which has an impact on the kind of culture. It is this hypothesis that is a focal point of the bases of the theory of cultural linguistics, in which a language is not only a means of conveying information, but also a representation of cultural heritage of a society, as information of ways of perceiving the world. It was the basis from which the conception of linguistic picture of the world started to develop within the framework of cognitive linguistics.

Ethnolinguistics developed in the United States, in the course of cooperation of ethnographers and linguists who did research on languages and cultures of the Indian tribes. In the small, isolated societies, so different from the developed, complex European societies, it was clearly visible how a language functions in the culture, what role it plays as an element of customs and a conveyor of beliefs and traditions from generation to generation. The observations based on the research of the Indian cultures and languages were compared with the results of the socially and culturally developed societies. The observation of the role of the language as a product of a given culture is a traditional object of linguistic research ${ }^{10}$. Although it had been prior to the beginning of ethnolinguistics, it intensified such analyses ${ }^{11}$. However, it should be emphasized that in antropolinguistics the new important question is posed whether culture influences the language or vice versa - it is the language which conditions a given culture? The reason for such analyses were the results of the already mentioned observations of Indian languages, in which researchers found grammatical and lexical phenomena completely different from the ones present in the European languages.

For example, the European time perception, i.e. continuous, might be considered the most natural, with the division into: past, presence and future. Such notions are not

7 Among his students were such scholars as M. Mead, A. Kroeber and R. Benedict.

8 The Polish translation titled Język-myśl-rzeczywistość was published in 1982. [15].

9 Eduard Sapir was an American linguist and anthropologist whose main work is Language. An Introduction to the Study of Speech [16].

10 Such analyses are devoted not only to lexis, but also to fixed expressions [17].

11 It is worth mentioning Polish journals and series devoted to such issues, for instance, the Język a Kultura [Language and culture] volumes published in Wrocław, the so-called "czerwona seria" [red series] published in Lublin, the journal "Etnolingwistyka" [Ethnolinguistics] familiar to the users of the Indian language Hopi, in which time is conceptualized as ,points”, i.e. indicating the phase of a process, e.g. momentalność, repetitiveness, distance in space-time; in the Polish language it reflects not as much as the kind of time as the activity (cf. odchodzić - 'move further in time and space' and nadchodzić - 'move closer here and now'). Instead of such relations, in Hopi, two processes are distinguished: objective, which really occurs or occurred, and subjective, which is a subject of thought, expectations, hopes (in a Polish perspective, it would be a future tense; however, this correspondence is only partial). The question could be posed whether such a perception is less developed. The answer is negative: it is another way - among many possible ones - of describing reality. Moreover, it is more precise and subtle in details than the perception of time in the European languages. The Hopi language has a rich scale of grammatical means used for describing vibrant movements, complying with such categories of modern theoretical physics, as the oscillating particle and the oscillation field, although it can be assumed that Indians did not know about it. Therefore, a question could be posed whether it might be easier to express certain scientific rules in Hopi ${ }^{12}$.

Furthermore, differences are observed in the terms describing colors [19]. The comparison of English names green, blue, grey and brown with the Welsh words gwyrdd, glas and llwyd shows that the relation of their equivalence is very complex [19]. The adjectives gwyrdd and glas are the counterparts of green and blue, with a semantic dominance of glas over gwyrdd, while the two other English terms, grey and brown, have only one equivalent llwyd [Appendix 1]. Another example is observed in the language of Navaho Indians who have only one name for green and blue, but they distinguish two kinds of black, imperceptible for Europeans [21-23]. It should be added that their language is very concrete: for instance, there is not word expressing the meaning 'to go', because each time the grammatical form should be indicated. Moreover, the means of transportation and speed have to be given, too, for instance, in a carriage or on a horse, slow or fast. The differences are not limited to distant cultures, since they are also found in the European languages: in the contrastive perspective, the Polish words drzewo, drewno, las and puszcza and their cross-linguistic equivalents, for instance, French arbre, bois and forêt, German Baum, Holz and Wald, and Danish träe and skov, also create a complex net of relations [Appendix 2].

Thanks to the observations regarding such differences, Sapir and Whorf formulated the already mentioned hypothesis concerning the relation of language and cognition. The most important assumptions are the following:

- human thinking is always thinking in a given language and by its means;

- the phenomena, whose names exist in a given language are distinguished by its users; important differences between phenomena are not perceived, if they are not

12 Other research studies were conducted by Lucy and Gaskins [18] on Yucatec Maya language, who discuss the difference on the categorization of nouns in this language in comparison with English. 
distinguished in the language (e.g. the Hopi Indians use one word for insect, plane and pilot);

- the linguistic pictures, which exist in the minds of persons speaking various languages, are completely different, and, what is more important, mutually untranslatable;

- the cognition of the world has a relative character, since it is done through the „filter” of words and grammatical categories of language.

The Sapir-Whorf hypothesis, called also - because of the last statement - the hypothesis of language relativity, inspired a discussion not only among linguists, but also among philosophers ${ }^{13}$. The authors of the hypothesis were accusing the negation of the possibility of objective cognition of the world and of overestimating the role of language as an intermediary between man and reality. Actually, in the extreme form, it is impossible to accept this hypothesis, since it ignores the fact that the lack of a name does not prevent distinguishing new objects in a given reality. A neologism or a multiword description can be used in such a situation ${ }^{14}$. The German verb reiten does not have a single-word Polish equivalent, but the meaning of the verb is expressed by the expression jeździć wierzchem.

However, it should be emphasized that the value of the basic Sapir-Whorf thesis is widely acknowledged. The thesis on the specifics of expressing phenomena by means of a given language is important also for another reason: it stimulated the opposite research trend, i.e. searching for universal elements confirming the fact that persons in various culture employ similar cognitive mechanisms, which is the object of psycholinguistic studies. To certain extent, such problems are also discussed for figurative language units [27], especially idioms and proverbs, which exist in an identical or similar form in many languages. Their presence can be observed not only in European languages, but also in distant ones, such as Japanese [28].

A modern man lives in a complex cultural environment formed over centuries. It influences man and defines his worldview, behavior and thinking. One of the elements of cultural environment, which is a result of the civilization development, a means of consolidation of its history and one of means of its modeling, is language and specialized lexis. According to Griniev [29], who stated this opinion at a conference held in Vienna in 1993 - it is specialized lexis that reflects the relation of language development and material and spiritual history of a language. According to Vinogradov, "the history of terminology is a novel of the development laws of science on nature and society".

Similar observations were also made by an eminent logician and philosopher, Gottlob Frege, ,.... what is known as the idea history, in fact, is either a history of our cognition or history of the meanings of words" ${ }^{\prime 15}$. Therefore, basing only of one collection of words in the Sumerian dictionary, one can

13 The kinds of research on language relativity are discussed by Rączaszek-Leonardi [24].

14 Multiword descriptive terms are commonly used in the case of such lacunae, both at the systematic and translational level $[25,26]$.

15 Own translation. form an opinion on the culture 3000 years B.C. In language philosophy, Frege's distinction between sense (in Frege Sinn) and reference (in Frege - Bedeutung). For example, a name, in Frege's terminology ,individual name”, like King Charles I, expresses a certain sense (a ruler of a given country) and has a concrete meaning (an existent person). In modern, linguistics, what Frege describes as a meaning is roughly equal to reference. The difference between sense and meaning can be observed in the case of expressions having sense, but not having a meaning, such as 'the first man on Mars'. The sense of the phrase, i.e. the first person who landed on Mars, may be comprehended by every language user, although it does not have a real meaning, since there is no person who has landed on Mars.

According to anthropolinguists, the changes occurring in a language enable following not only the development of particular branches of science and culture, but also the development of human awareness. Anthropogenesis reflects its gradual progress; therefore, new areas of mind can be explored. In the evolution of thinking processes it is possible to analyze particular stages and the amount and properties of lexical stock used within given periods. Analogous changes in man are observed in ontogenesis, i.e. individual development of man, which confirms the theory of parallel character of phylogenesis and ontogenesis, formulated in biology as biogenetic law, also enables reconstructing man's mentality at given stages of his evolution.

Since, to a great extent, the result of semantic research is often treated as inconclusive - which is often based on some general observations - it is worth emphasizing that the value of such analyses should not be questioned. The discussion on the language evolution (or the evolution of language) requires more in-depth studies. The role of anthropological linguistics in the research on man evolution, in the case of human intellect, is definite: directed towards a reliable, verifiable, devoid of ideological influence, scientific approach to the research task, which is difficult and tends to be heavily criticized. That is why, irrespective of a vast amount of literature, the issues related to the origin of language are still of interest, in particular the evolution, thus "language' and "thinking". The interdisciplinary character of such studies also involves the participation of non-linguists, who will conduct research, in which the main problems result from the multi-faceted character of research material.

Although research on anthropology of language and related subjects had been conducted for long time, it was only in the eighties of the $20^{\text {th }}$ century that a constant increase of interest in this area was observed. Nowadays such research constitutes an important part of linguistics, being one of the most dynamically developing areas of linguistics. The number of scientists involved in linguoanthropological research is increasing, especially in Poland and Russia ${ }^{16}$. More in-depth studies focus on the

16 The following terminologists favour the anthropological assumptions: E. Sorokina and L. Tkaczow from Russia, J. Arabski and R. Kowalczuk from Poland, A. Steponavičus and J. Korsakas from Lithuania as well as I. Burłyka from Belarus. The representatives of other disciplines also adopt an anthropolinguistic approach, for instance, M. Iwanowski, M. Koczerhan, C. Lachur and M. Łesiów. 
development of the branch [30]. In fact, many notions and assumptions are more complex than it had been expected. Therefore, more studies and analyses are necessary and the multiaspectual approach has to be adopted. Thanks to interdisciplinary research of broad scope, it is possible to efficiently analyze particular elements of the research objects. It should be stressed that the practical aspect of such research is important, too.

In the modern world, in which the progress is rapid, the development of science is also much more intense. In June 2014 [30], the tenth volume of the series Edukacja dla przyszłości [Education for future] was published. It contains the papers written by scientists from Poland, Russia, Belarus, Lithuania and Poland, who discussed various issues from the field of anthropolinguistics. The articles deal mostly with linguistics, but they also touch upon other areas of the humanities. In the foreword, the aims and the circumstances, in which the volume was published, are presented. New areas have been researched by means of anthropolinguistic methodology [31]. Moreover, in 2015, Gryniewicz, Thomas and Sorokina published a book titled Foundations of Anthropolinguistics [32]. To conclude, it can be said that the interest in the anthropolinguistic research conducted by scholars specializing in various disciplines is increasing, which is reflected in the number of publications and the variety of the subjects discussed by the scholars.

\section{Acknowledgements}

The authors would like to thank the editors and the anonymous reviewers for their comments on the paper.

\section{Appendix}

1. The relation between the English color names green, blue, grey and brown to their Welsh equivalents gwyrdd, glas and llwyd [18]

\begin{tabular}{|cc|}
\hline English & Welsh \\
green & gwyrdd \\
& \\
Blue & glass \\
Grey & \\
Brown & llywd \\
\hline
\end{tabular}

2. The comparison of the Polish lexemes drzewo, drewno, las and puszcza with their French, German and Danish equivalents [18]

\begin{tabular}{|cccc|}
\hline Polish & French & German & Danish \\
drzewo & Arbre & Baum & träe \\
Drewno & & Holz & \\
& bois & & \\
Las & & Wald & Skov \\
Puszcza & forêt & & \\
\hline
\end{tabular}

\section{REFERENCES}

[1] Foley WA. Anthropological Linguistics. Malden. MA: Blackwell; 1997.

[2] Griview-Griniewicz S. Raube S. Thomas P, editors. Language and Culture: Establishing foundations for anthropological linguistics. Białystok: Wydawnictwo Wyższej Szkoły Finansów i Zarządzania w Białymstoku; 2004 (Bialystok Series of Anthropolinguistics, Vol. 1).

[3] Гринев-Гриневич СВ. Сорокина ЭА. Скопюк Т Г. Основы антрополингвистики (к лексическим основам мышления человека). Москва: Moscow Pedagogical State University; 2005.

[4] Strelau J. Psychologia: Podręcznik akademicki. Tom 1. Podstawy psychologii [Psychology: A university coursebook. Volume 1. The Basics of psychology]. Gdańsk: Gdańskie Wydawnictwo Pedagogiczne; 2000. P. 639.

[5] Hoad TF. The Concise Oxford Dictionary of English Etymology. Oxford: Oxford University Press; 1993. P. 20.

[6] Battisti C. Alessio G. Dizionario etimologico italiano. Vol. 4. Firenze: G. Barbèra Editore; 1975. P. 3010.

[7] Nosowicz JF. Szerszunowicz J. On the idioms containing components of unrestricted variance in a contrastive perspective. In: Nosowicz JF. Pazera J, editors. Edukacja dla przyszłości. Vol. 5. Białystok: Wydawnictwo Wyższej Szkoły Finansów i Zarządzania w Białymstoku; 2008. P. 127-135.

[8] Chruszczewski P. Językoznawstwo antropologiczne. Zadania i metody [Anthropological linguistics. Objectives and methods]. Wrocław: Oddział Polskiej Akademii Nauk we Wrocławiu; 2011.

[9] Malinowski B. Dzieła. T. 2. Zwyczaj i zbrodnia w społeczności dzikich; Życie seksualne dzikich w północno-zachodniej Melanezji [Works. Vol. 2. Crime and Custom in Savage Society. Sexual life of savages on north-western Melanesia]. Warszawa: PWN; 1980.

[10] Nosowicz JF. Terminologizacja a szybkość zmian językowych [Terminologisation and change rate]. In: Language and Culture: Establishing Foundations for Anthropological Linguistics, Białystok: Wydawnictwo Wyższej Szkoły Finansów i Zarządzania w Białymstoku; 2004. P. 97-105.

[11] Szerszunowicz J. A Comparative Analysis of Small Talk in 
English and Polish. In: Berlin LN, editor. Theoretical Approaches to Dialogue Analysis. Selected Papers from the IADA Chicago 2004 Conference. Tübingen: Niemeyer; 2007. P. 39-48.

[12] McArthur T, editor. The Oxford Companion to the English Language, Oxford: Oxofrd University Press; 1996. P. 797.

[13] Lavrova A. Special Languages (LSP) and Anthropological Linguistics (AL). In: Obdobja 2007 [cited 2015 Aug 14]; 24:29-32. Available from: http://www.centerslo.net/files/file/simpozij/sim24/lavrova.pd f.

[14] Lachur Cz. Zarys językoznawstwa ogólnego [The outline of general linguistics]. Opole: Wydawnictwo Uniwersytetu Opolskiego; 2004. P. 248.

[15] Whorf B. Język - myśl - rzeczywistość [Language - thought reality]. Warszawa: PIW; 1982.

[16] Sapir E. Language. An Introduction to the Study of Speech. Yale: Harvest Books - Harcourt, Brace, and World; 1921.

[17] Szerszunowicz J. Linguo-Cultural Analyses of European Phraseological Units in a Contrastive Perspective. In: Yagi K. Kanzaki T. Inoue A, editors. Phraseology, Corpus Linguistics and Lexicography. Papers from Phraseology 2009 in Japan. Nishinomiya: Kwansei Gakuin University Press; 2011. P. 115-132.

[18] Lucy JA. Gaskins S. Grammatical categories and the development of classification preferences: A comparative approach. In: Language Acquisition and Conceptual Development. Cambridge: Cambridge University Press; 2001. P. 257-283.

[19] Wierzbicka A. O języku - dla wszystkich [On language - for everybody]. Warszawa: Wiedza Powszechna; 1965. P. 165.

[20] Szerszunowicz J. Językowy obraz świata w glottodydaktyce [The linguistic picture of the world in teaching foreign languages]. In: Nosowicz JF, editor. Edukacja dla przyszłości. Vol. 2. Białystok: Wydawnictwo Wyższej Szkoły Finansów i Zarządzania w Białymstoku; 2005. P. 212.

[21] Brown R. Lenneberg E. A study in language and cognition. Journal of Abnormal and Social Psychology 1954;
49:454-462.

[22] Heider ER. Universals in color naming and memory. Journal of Experimental Psychology Apr 1972; 93(1):10-20.

[23] Davidoff J. Davies I. Roberson D. Colour categories in a stone-age tribe. Nature 18 March 1999, 398(6724):203-204.

[24] Rączaszek-Leonardi J. Zjednoczeni w mowie. Względność językowa w ujęciu dynamicznym [United in speech. Language relativity in a dynamic approach]. Warszawa: Scholar; 2011. P. 24-29.

[25] Szerszunowicz J. On Lacunae in Contrastive Phraseology. In: Fabčič M. Fiedler S. Szerszunowicz J, editors. Phraseologie im interlingualen und interkulturellen Kontakt. Phraseology in Interlingual and Intercultural Contact. Maribor: Zora; 2013. P. 161-175.

[26] Szerszunowicz J. Kulturem we frazeografii dwujęzycznej [The cultureme in bilingual phraseography]. In: Nosowicz J, editor. Edukacja dla przyszłości. Vol. 10. Białystok: Wydawnictwo Wyższej Szkoły Finansów i Zarządzania; 2014. P. 295-306.

[27] Dobrovol'skij D. Piirainen E. Figurative Language: Cross-Cultural and Cross-Linguistic Perspective. Amsterdam: Elsevier; 2005.

[28] Piirainen E. Widespread Idioms in Europe and Beyond. Towards a Lexicon of Common Figurative Units. New York: Peter Lang; 2012.

[29] Grinev SV. Terminology Research in the Former USSR. In: Kewley Draskau J, editor. Selected Readings in Russian Terminology Research. Vienna: TermNet; 1993.

[30] Nosowicz JF, editor. Edukacja dla przyszłości [Education for future]. Vol. 10. Białystok: Wyższa Szkoła Finansów i Zarządzania w Białymstoku; 2014.

[31] Nosowicz JF. Korsakas J. Slovo v uczebnom processe. Słowo $\mathrm{w}$ procesie nauczania [The word in the teaching process]. Białystok: Wydawnictwo Wyższej Szkoły Finansów i Zarządzania w Białymstoku; 2006. P. 1-224.

[32] Griniewicz S. Thomas P. Sorokina E. Foundations of Anthropolinguistics, London: Lambert Academic Press. 